University for Business and Technology in Kosovo

UBT Knowledge Center

Oct 27th, 3:15 PM - 4:45 PM

\title{
The Traditional Tower Houses of Kosovo and Albania -Origin, Development and Influences
}

Caroline Jaeger-Klein

Technische Universität Wien, jaeger-klein@tuwien.ac.at

Follow this and additional works at: https://knowledgecenter.ubt-uni.net/conference

Part of the Architecture Commons

\section{Recommended Citation}

Jaeger-Klein, Caroline, "The Traditional Tower Houses of Kosovo and Albania -Origin, Development and Influences" (2018). UBT International Conference. 27.

https://knowledgecenter.ubt-uni.net/conference/2018/all-events/27

This Event is brought to you for free and open access by the Publication and Journals at UBT Knowledge Center. It has been accepted for inclusion in UBT International Conference by an authorized administrator of UBT Knowledge Center. For more information, please contact knowledge.center@ubt-uni.net. 


\title{
The Traditional Tower Houses of Kosovo and Albania - Origin, Development and Influences.
}

\author{
Caroline Jaeger-Klein ${ }^{1}$ \\ ${ }^{1}$ Vienna University of Technology, Department for History of Architecture and \\ Building Archaeology, Karlsplatz 13/251; \\ A-1040 Vienna, Austria \\ jaeger-klein@tuwien.ac.at
}

\begin{abstract}
Gheg-Albanians as well as Tosk-Albanians consider a distinct tower-house type of their traditional heritage. The closer look upon the structures in their geographical distribution from the Dukajin plains in nowadays Kosovo into the Dropull valley in Southern Albania provides a wide range of variations. Generally those structures served as impressive residential houses (banesa) for rich landlords, warlords, tax collectors and merchants performing a ruralurban lifestyle. Therefore, a sophisticated blend of the all-time defendable Albanian tower house (kulla), still existing quite intact in the western Kosovo plains, and the comfortable Turkish lifestyle influenced residence was developed during the long centuries of the Ottoman rule over Western Balkans. In the later 19th century, within the important trading towns of the southeastern Balkan Peninsula also Western European ideas of National-Romanticism seemed to have led to the transformation of the rural kulla type of the Dukajin plains into the totally urban kullat of Gjakova and Peja.

With the distinct knowledge of the widely renowned Albanian interdisciplinary craftsmanship of masons and carpenters, - well organized under master craftsmen for the planning and contracting -, stunning and sophisticated building structures were successfully erected on most difficult morphological sites, fulfilling different wishes of their multi-ethnical clients all over the Ottoman Empire. Additionally to the solid and earthquake resistant stone basements, light-weight construction methods of plastered wooden lath (bondruk-technique) for upper floors guaranteed an expanded climatic comfort for the hot seasons and avoided heavy damage in the seismic emergency case for the quite high-raised houses.

The article tries to trace the different cultural influences transforming the original stone-tower houses probably kept for a long time in their Mediterranean-Medieval original configuration over the course of the times. Besides, the 19th century Austrian descriptions give a deeper insight into the usual workflow of the craftsmen troops from the Dibra region, responsible for the mason carpenter structures, the gypsies (Egyptians), which they contracted for the metal work and the stone mason specialists from the Adriatic coast, who were in charge of specific fortification features.
\end{abstract}

Keywords: Albanian kulla and banesa, rural-urban traditional architecture, mason-carpenter structures, earthquake resistant construction, fortification and defense characteristics, Ottoman life-style, comfort 


\section{Introduction}

Nowadays Albania and Kosovo always have been positioned at the crossroads of cultural spheres. Due to its geographic position, within its territories already in ancient times Eastern and Western influences met. During the first millennium after Christ, the administrative as well as religious differences between Latin Rome and Byzantine approaches grew constantly. In 1054, the Christian Balkan World divided officially in Roman Catholicism and Byzantine Orthodoxy and from 1018 to 1204, also the profane administration of most parts of nowadays Kosovo and Albania resorted under Byzantine rule. Only the Croatian coast towns and the North of Albania remained under Latin episcopal and Venetian economical influence, whereas the Greek Byzantine culture and religion dominated clearly the south. East of the mountains already in the $12^{\text {th }}$ century the Serbs of Rascia managed to take over political as well as religious power, which lasted until the Ottoman conquest starting with the mythical battle of Kosovo in 1389. Other parts of the region resisted the foreign domination for more than another century, thanks to heroic native lords like Scanderbeg (who died in 1468) or Christian bishoprics like Dyrrachium (Durres), which fell in 1501. Officially, the Ottoman Empire ruled the region into World War I, followed by several kingdoms, partially under foreign influence. After World War II various socialistic/communistic regimes dominated, until the general collapse of the former Eastern bloc brought back the region into influence spheres of the West. If there is constancy within the history of the region, it manifests itself through the permanent shift between East and West, which the rich architectural heritage of the territories mirrors intensively.

But how could those shifting influences reach the region so effectively? The major trading routes connecting Rome with Byzantium/Constantinopolis (Istanbul) and crossing through the region are one driving factor. During ancient epochs, the Via Egnatia as well as the Roman roads connecting Lissus (Lezha) and Saloniki with Naissus (Nis) and the Danube region, allowed the permanent exchange of various influences. In medieval times, an even denser road network (Via de Zenta, Via de Bossina), starting from several Adriatic coast towns south of Ragusa (Dubrovnik) reached finally Constantinople via Kosovo and Albania and provided the Venetian as well as the Florentine markets permanently with fresh money from the silver mints of the region. The organization of the Balkan inlands trading system lay in hands of few trading families from Ragusa (Dubrovnik) and Kotor and passed away in 1526, when the Republic of Ragusa fell into the hands of the Ottoman regime. These strong connections to major economic and cultural centers of Europe as well as Eastern Asia explain the various Italian and later Ottoman influences and enriched the built heritage of nowadays Kosovo and Albania.

\section{Traditional Residential Houses of Albania and Kosovo}

\section{Albanian residential house types and life-style}

Besides, the Albanians are without doubt survivors of the Balkan natives from classical times and at present differentiated from neighbors by religion and general culture [1]. Certainly their specific Albanian life-style in combination with exceptional skills in building crafts shaped fundamentally their architecture beyond all foreign influences and fashions. When Kiel summarizes, that "the history of the country is that of occupation by foreign rulers and the struggle of minor native lords against these foreigners or among themselves" [2], we have to assume, that defense features characterize the traditional residences of the Albanians in a specific way. 

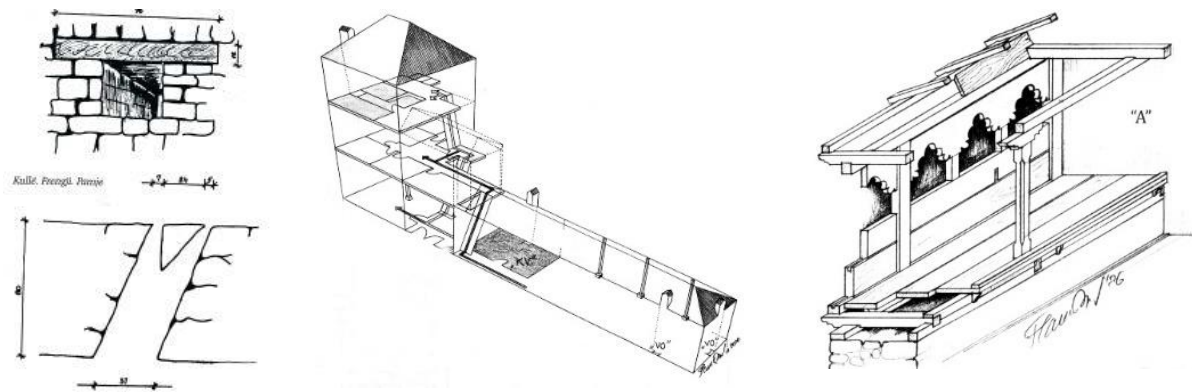

Fig. 1. Defense features of traditional Albanian houses: loop holes for rifles (frengji - left), strict separation of internal and external stairway systems (center) and sitting gallery or balcony for overviewing the surroundings (dyshekllek - right); drawings by Flamur Doli

In contrary to the major Adriatic coastal cities, which were used as "springboards for the expressionist schemes of several Mediterranean powers", and therefore left in principal "fortress works as their legacy" [3], in the far less densely populated mountain regions and highlands, the settlement schemes are different. Johann Georg von Hahn describes around 1850 the region with "households ... that are scattered about, in Albanian fashion, either as individual farmhouses or as loosely settled neighborhoods that all fall under one name" [4]. Those distinct characteristics of Gheg (the northern group) Albanian settlement culture survived in the west of nowadays Kosovo along the Dukagjin plains. Dranoc combines some of those specific tower-houses, which the literature [Flamur Doli, 1993, 2001, 2009; Emin Riza 2006, 2009, 2010, 2013] names Albanian (or Schiptar's) kulla (alban. kulë; pl. kullat), to densified settlements in the tradition of the Byzantine pirgos [5]. That fortress like compounds made up through a distinct way of grouping several kullat is named mat.

Interestingly, the same literature names the other type of domestic structures banesa (pl. banesas), expressing its major function as comfortable dwellings, as residences. Herein, the national attribute is normally skipped, indicating the awareness that this type might represent a rather big portion of Ottoman life-style that transformed the Albanian upper classes during the long lasting rule of the Turks. That type of residential buildings is used for the manors of the wealthy landlords equally to the ones of the tax collectors and other high-ranked administrative family houses both based themselves within important rural settlements or urban trading centers. This building type signals to the passing-by a certain will of incorporation of its inhabitants into the Ottoman political and administrative world. In its physical appearance, here no longer the defense character of the Albanian tower house is normative, but the comfortable wealth of those, who have arranged with the ruling regime as well as the ruling climate of the region.

Hence, also on Balkans in the $18^{\text {th }}$ and especially the $19^{\text {th }}$ centuries life of the people changed fundamentally. "The migration of the population - and with it the architecture of the traditional country house - towards the cities ... was a consistent and regular process. The clear genetic and typological link between the town house and the country house in the town's adjoining region is due to this migration"[6]. This process is still in particular visible in western Kosovo, in the adjacent towns of the Dukagjin plains Peja and Gjakova. The originally rural tower house type of Dranoc and Junik, the kulla, was re-launched as urban and more modern residential type in the neighboring market centers. If the genesis of those late urban tower houses (kullë qytetare) had an additional political motivation caused by the national-romantic League of PrizrenMovement, seems not yet researched.

In the south of Albania and specifically noticed for Gjirokaster, the reverse process seemed to have happened within the $18^{\text {th }}$ and early $19^{\text {th }}$ centuries. Here, around the market town core on the foot of a fortress, several additional neighborhoods (mahale) of traditional tower-houses scattered 
on the extremely steep, rocky southern slope above the Dropull valley. Those tower-houses are a remarkable blend of the traditional (Italianate) stone-tower houses with the more luxurious dwelling models of Salonica (Thessoloniki) and Stambul (Istanbul) that returned back to Gjirokaster together with the trading and warfare expeditions of its distinct society.
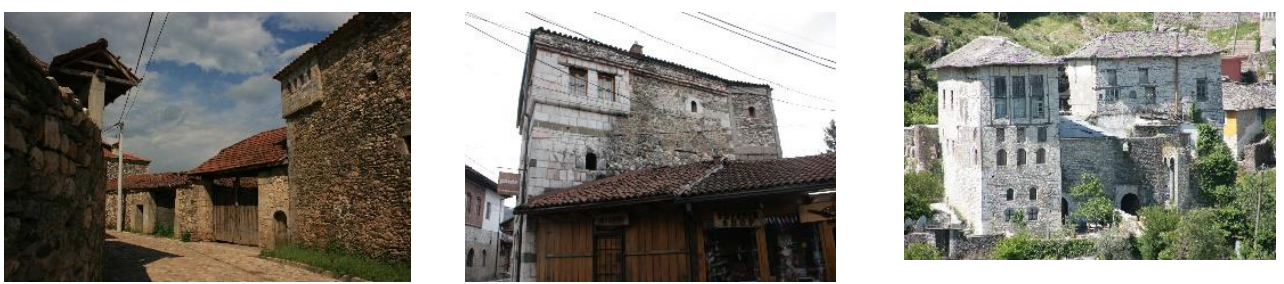

Fig. 2. Traditional tower houses combined to a fortress-like compound in the countryside (Dranoc - left); urban tower house in the middle of the market area (Gjakova - center); freestanding, comfortable tower residences forming a neighborhood (Gjirokaster - right); all photographs by Jaeger-Klein

\section{The buildings and their functions}

The settlement patterns and house types of the Northern Albanian Gheg vary from district to district, resembling their tribal and clan system as well as different natural resources and climatic conditions. Yet, the northern Albanian tower-house type is unmistakably distinct in its physical appearance. "The kula is a three storey building of rectangular plan, whose sides are 7-8 $\mathrm{m}$ (23$26 \mathrm{ft}$ ) high; it is built with heavy stone walls, $70-80 \mathrm{~cm}(27-31 \mathrm{in})$ thick, with no or very small vaulted openings or rifle loopholes on the ground, which become more numerous towards the upper storeys. On the top floor, there are living-quarters with a sitting space (divanhana). This floor is built in light material, mainly of wooden skeleton with larger openings frequently forming a sitting balcony or an enclosed wooden chardak, a much lighter room than those below. The raised sofas (dysheklleku) covered with kelims are very much comfortable. The overlooking view, for control and inspiration, seems also to be an important criterion for such a house form." [7]. For matters of security, a sophisticated stair concept is provided; the only way to reach the upper floor is by means of an outside, wooden staircase, which in case of an attack is burnt. Then the circulation of the house is completely autonomous inside the solid stone shaft of the tower house. During the daily use of peacetimes, the basement of the tower houses are serviced from the enwalled yard, but can also be reached through an inner wooden staircase down from the family (women and children) floor. There the rooms are separated by thin walls of wooden planks. The comfortable and representative upmost floor with the sitting balcony or gallery in stone or wood was the area for the men and their guests. More of the description of Prodanović, that some Albanian kullat are "divided vertically into women's and men's quarters according to Islamic rules", we never could verify. The basement of the tower house with kitchen, storage and room for the cattle is only accessible from the grounds of the yard enwalled in stone completely. A huge, roofed door with heavy wooden planks armed in metal is the usual and distinct entrance to the yard. 

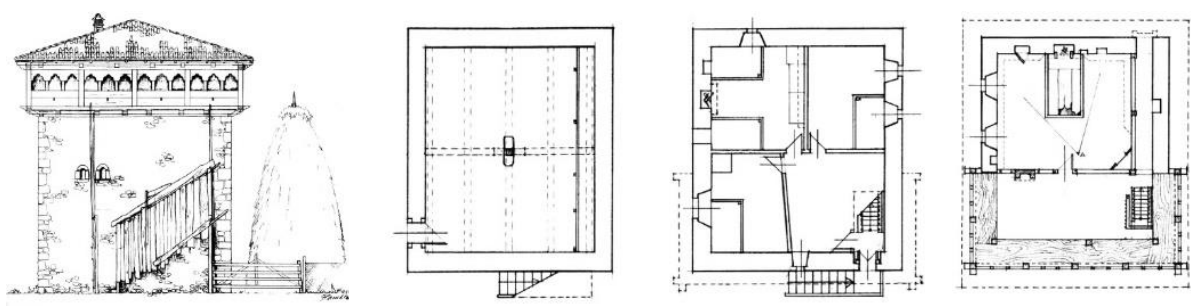

Fig. 3. Floors plans and elevation of a typical northern Albanian (Gheg) tower-house from the plains of Dukagjin: The kulla of Hysen Haxhijajt, erected 1826 in Carrabreg i Ulët; all drawings by Flamur Doli

The Zekate house is the eye-catching tower house structures of Gjirokaster and represents pretty authentic the southern Albanian Tosk type of the wealthy Albanian early 19th century residence. The particular grand fortified tower house was constructed in 1811-12 by Beqir Zeko, a general administrator in Ali Pasha's government. Through an imposing front door you reach the lower hall with attached the storeroom for milling cereals and the large water cistern. The first floor contained the lower divan for guest receptions and central kitchen, situated directly on top of the cooling cistern. Hence, this arrangement is unusual, as the other important manor houses of Gjirokaster do provide the kitchens' in closer spatial connection to the family apartments. The second floor contains the rooms for the two branches of the family, arranged around the central divan. All of the rooms are provided with low couches running around three sides of the room and smaller storage cupboards built into the walls. Within the largest wooden cupboard (musandra) at one end, the mattresses and other bedding equipment is stored during the day. It additionally covers the entrance door and adjacent toilet. This musandra conceals a short staircase leading to a small gallery overlooking the room, where women and children retired during formal meetings. The third floor resembles this room display. The two smaller rooms are summer chambers following the model of the (winter) rooms on the floor below. The grand reception room is defined through its magnificent open fire-place, elaborately decorated with frescos and a finely carved and gilded ceiling. It provided a spectacular view over the town and the valley below and was used for the most important social occasions. For the daily use, we have to follow the final statement of the Gjirokastra Foundation: "An important feature is the general lack of a distinct gender division between selamlik (male) and haramlik (female) quarters"[8]. Also the description of the daily family life within his own family house in Gjirokaster, which the famous Albanian novelist Ismail Kadare gives in Chronicle in Stone, does not tell any opposite. 

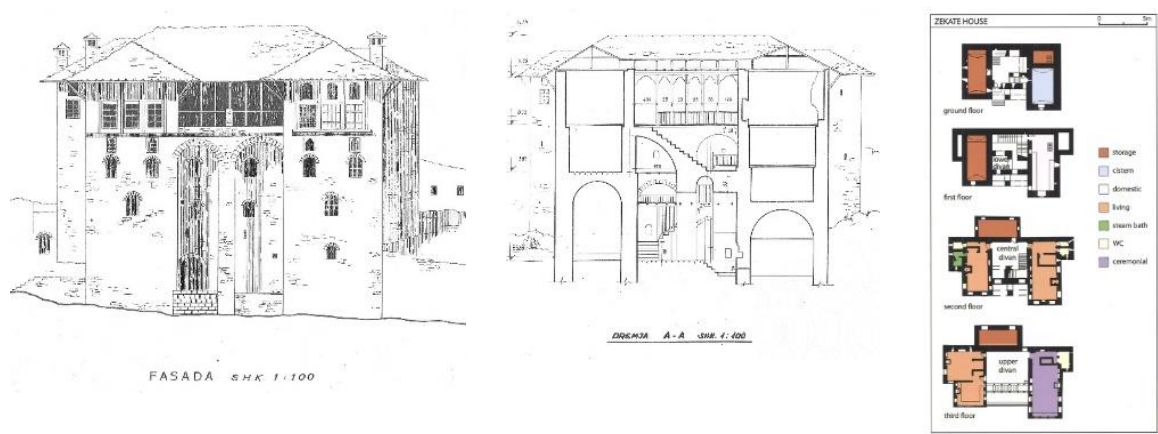

Fig. 4. Floors plans and elevation of a typical southern Albanian (Tosk) tower-house from the Dropull valley: The kulla of Beqir Zeko, erected 1811-12 in Gjirokaster; elevation and section in plans from: Nga Thesari I Arkitekturës Sonë 1977; plan with functions - GCDO 2009, p.39

Finalizing the description of 19th century social life in Gjirokaster, Johann Georg von Hahn is again helpful. "They (the landed gentry of Gjirokaster) live in high-rising solid homes that have only loopholes and embrasures on the main floor, but high windows on the third and fourth floors. The courtyards are protected by high solid walls, and the heavy gates are usually in double rows. The outer gate leads to a small forecourt that can be reached from everywhere in the interior of the house. The inner courtyard is situated so that one cannot see it from the outer courtyard. ... In peacetime, when the parties who had divided the town up themselves were in conflict - and this situation was often the norm - they used their retainers to protect their homes and wasted a lot of gunpowder by shooting from behind their walls at the embrasures of the neighboring houses with which they were in conflict. As they all remained behind protective walls, blood was rarely spilled in the urban wars."[9]

\section{Material and Craftsmanship}

In material and construction techniques, the traditional Albanian tower houses differ according to local resources and climatic conditions. In the high plains of Kosovo or in the flatlands along the Adriatic coast, mud bricks are more often used, whereas stone is certainly the dominant material for all mountain areas. Besides this fact, they all are mason-carpenter structures, which already Johann Georg von Hahn mid-19th century studies definitively stressed. He, quite extent reports on the Albanian craftsmanship, for example that they came "in particular from the regions of Kolonja and Dibra. There, not only whole villages but whole regions have one and the same profession. All the men in European Turkey and in the kingdom of Greece who build walls, fell trees and saw lumber are from Albania, almost without exception. There are areas that are inhabited exclusively by traditional woodcutters, sawmill people and diggers. These professions are carried out by journeymen who wander in groups under their master craftsmen and take pack animals with them to carry the material they need. It is said that there are 6,000 Epirot labourers employed in Constantinople and the surrounding region." Hahn tells us further that they spend their summers in the healthy air of their mountainous homelands to stay healthy, and that they join forces for major work, but more often separate into smaller groups to work in different places at the same time. "A group of masons rarely consists of less than twenty men. Woodcutters are often in larger groups, and diggers from northern Albania often consist of over 100 men in a group. The master craftsman arranges the contracts and is often not on site with them so that he can look around for more work. The contracts usually involve a certain amount of money for a cubic cell ..., which is the equivalent of two feet, but there are also contracts for day wages or for the job as whole." [10] 
This explains pretty well their flexibility and smartness to use the available materials according to specific circumstances, no matter if war, earthquakes or extreme climate were the challenges. Only the more peaceful periods seem to have allowed foreign specialists to sneak into that local business. So, it seems that the wish for more prestigious Gheg-Albanian tower houses in the 19th century called some advanced stone-cutters, probably from Dalmatia (the medieval monastery church of Decan in the same neighborhood is reported to be made by master masons from Kotor), into the Dukagjin plains. All of a sudden, the former wooden dysheklleku (outlook galleries) are now made of stone, neatly translating their characteristic features of carpentry into sophisticated miniature galleries from cut stone.

For the south, already the historic Turkish travel report from Celebi in 1670 stresses the exceptional quality of the stonework in Gjirokaster. "The manner in which the outer walls of all the houses are constructed has no parallel in all the world. They are all twenty ells high (approximately 15 meters) of red sandstone blocks, just stone on stone with no mud, lime or plaster. The walls and the houses are all centuries old, dating from the time of the infidels. The walls are so lofty and solid that not even a sparrow can get a clawhold"[11]. For the Zekate house, the quality of the stonework is even connected to its master craftsman. As the house was built in the times, when Ali Pasha Tepelena made Gjirokastra to his headquarter of the region, his preferred fortification engineer Petro Koçari worked also for the Zeko family [12]. This fact explains the sophisticated load bearing structure of the four-storeyed, grand tower house. The two arches of the kamerie and the two vaulted rooms covering the whole basement enclose the structural core of the building with the cistern and the several staircases on vaulted supports, all made of stone.
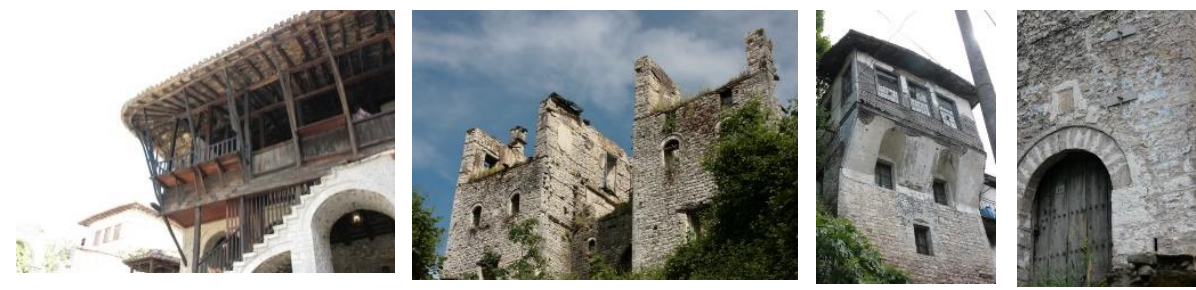

Fig. 5. Traditional Albanian crafts do not divide into masonry and carpentry: the sophisticated wooden roof structure of the Ethnographic museum house in Berat (left); horizontal wooden reinforcement of a double shell stone structure wall (Gjirokaster - center left); lightweight upper floor in bondruk construction method (Gjirokaster - center right); the arched doorway is probably constructed from foreign stone mason specialists, the metal work by local gypsies (Gjirokaster right); all photographs by Jaeger-Klein

\section{Earthquake proof and comfortable structures}

Heavy earthquakes any times have shaken the whole region. Therefore the classic Byzantine architecture, which was carried on through the later times by the orthodox building tradition, preferred burnt brick structures with extent mortar joints for matters of elasticity. The Albanians seemed to have reacted, for whatever reasons, differently on the permanent threat. They hang on their structures of stone instead, but reinforced them with wood. Horizontal layers of pinewood every 80-120 centimeters, connected with shorter binders through the 70-120 centimeter thick walls, distribute the loads like frames and additionally give certain elasticity, both features supportive in case of emergency. Maybe they did not trust in brick masonry for reasons of defense; certainly stone masonry was also considered to be more prestigious and more adequate for a heroic warriors' culture, which was kept as kind of national identity all through the times and its foreign administrations. On the other hand, in times of inner and outer fights and conflicts, as permanent a threat as earthquakes, the protection behind a solid shell of stone proofed to be a 
solid solution over the course of the years. Especially in case of fire, the perimeter stone walls outside protected the interior wooden staircases and ceilings quite effectively. In Gjirokaster, but also other regions, even the roofs are made from stone plates, which for earthquake cases is quite dangerous, but very effective in case of fires, shooting and suddenly heavy rainfalls.

With the times becoming more peaceful, the stone walls of the upper stories vanished and were replaced by lightweight structures, additionally providing far more climatic comfort, but also a certain safety in case of earthquakes. For Berat, it is documented that after the serious earthquake from 1851, the constructive system was remodified [13]. The Gjirokastra Foundations summarizes material and construction of the upper (summer) floor with all experience from restoration: "The walls are wooden lath covered with a special plaster compound produced from a mix of aged lime, goat hair, egg whites, fine sand, mixed with straw".[14]

It seems that this was the traditional way of building, but after the serious damage of Berat in 1851 and already with the society changed to a more peaceful way of living together, the lightweight solution for the upper parts of the houses took over. The younger solution additionally allowed much more climatic comfort during the hot season. Gjirokaster is centrally positioned on the Western side of the Drinos valley, "on the north-east slopes of the mountain Mali I Gjerë, which separates the valley from the Mediterranean region" [15]. Therefore, it shows a rather extreme climate with generally hot and dry summers, but cold and wet winters. Especially the intermediate seasons surprise with enduring heavy rainfalls. The Gjirokaster building tradition shows interesting answers on such specific climatic conditions. As they are so far completely unsearched in terms of measurements and simulations, here we can just describe first glimpses. "The house has normally a tall basement, above which the first floor was for use in cold season, and the second floor for the warm season [15]." The concept was comfortable for its inhabitants and in generally a climate friendly architectural design: The surrounding stoned walls of the winter floor "made them easier to heat. Each has an adjacent toilet and bathroom (hamam), which were heated by the fires in the main rooms," the GCDO describes in detail the Zekate House [14], whereas the summer rooms are all situated within the "uppermost timber gallery", where you even nowadays feel the light breeze coming through the wooden lath only covered with plaster. Additionally "the windows, bar the lunettes with their multicolored glass, are unglazed to allow a cooling draft."'[12]

Herewith the building tradition of adjacent Thessalia, the neighboring region belonging to nowadays Greece, shows up. Eleftherios Pavlides describes the Thessalian towns the following: "The large mansions of the mercantile towns of Pelion, Ossa, Olympus and Pindhos had three levels which were seasonally zoned. The first two levels were built in the masonry base. They consisted of a storage space on the ground floor, and a 'winter zone' with fireplaces and small windows facing south on the second floor. The top floor, the 'summer zone', consisted of light frame construction cantilevering over the base, with numerous windows to capture the summer breeze and frame distant views.”[16] 

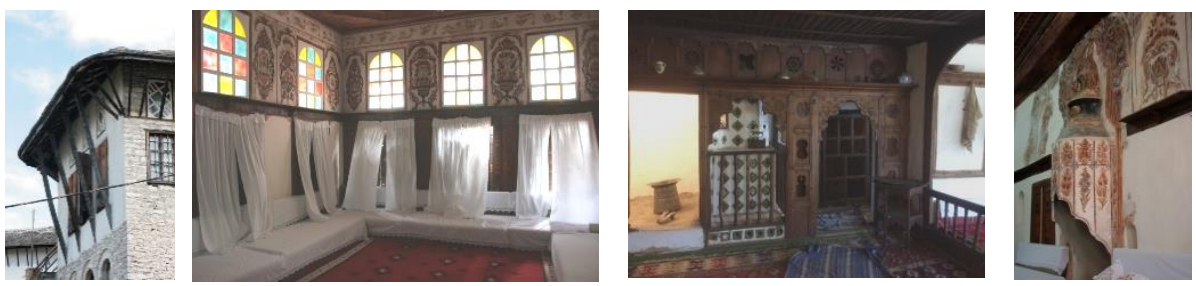

Fig. 7. Comfortable structures through smart adaptation to the climate: the summer-floor with the light breeze floating through the rooms (Gjirokaster - left and center left); different heating facilities for winter like the hamam-chimney-combination in the Emin Gjiku complex of Prishtina (center-right); chimney in the most representative room of the Zeka house (Gjirokaster - right); all photographs by Jaeger-Klein

\section{Concluding Remarks}

It can be stated with certainty that through its strong trading connections to the cultures of the East as well as the West, the traditional Albanian tower houses, originating in the uncomfortable tower houses of stone around the Medieval-Mediterranean, could enhance their comfort as well as security standards to astonishing results. This process probably took place during the late $18^{\text {th }}$ and $19^{\text {th }}$ century. Nevertheless the inherited and carefully safeguarded carpenter-mason craftsmanship in special regions like Dibra enabled the Albanians to build up a strong reputation within the Ottoman as well as the European elites for elaborate results in the segment of advanced residential housing. How much this particular international experience has influence the transformation of the originally rural type of house into an expression of the urban lifestyle during the national-romantic movement of the League of Prizren at the end of $19^{\text {th }}$ century, seems so far still not yet researched at all.

\section{References}

1. Prodanović, Milan, p.1488 in: Paul Oliver (ed.), Vernacular Architecture of the World, London 1997, Part 2.IV.3 Balkans, p.1483-1499.

2. Kiel, Machiel, Ottoman Architecture in Albania (1385-1912), Istanbul 1990, p.15.

3. Kiel, Machiel, Ottoman Architecture in Albania (1385-1912), Istanbul 1990, p.16.

4. Von Hahn, Johann Georg, The Discovery of Albania. Travel Writing and Anthropology in the Nineteenth-Century Balkans, selected texts introduced and translated from the German by Robert Elsie, London 2015, p.90.

5. Prodanović, Milan, p.1489 in: Paul Oliver (ed.), Vernacular Architecture of the World, London 1997, Part 2.IV.3 Balkans, p.1483-1499.

6. Anguelova, Rachelle, p.1485 in: Paul Oliver (ed.), Vernacular Architecture of the World, London 1997, Part 2.IV.3 Balkans, p.1483-1499.

7. Prodanović, Milan, p.1489 in: Paul Oliver (ed.), Vernacular Architecture of the World, London 1997, Part 2.IV.3 Balkans, p.1483-1499.

8. GCDO with Booth, Felicity, Roshi, Elenita, (ed.), Gjirokastra. The essential Guide, Tirana 2009, p.40.

9. Von Hahn, Johann Georg, The Discovery of Albania. Travel Writing and Anthropology in the Nineteenth-Century Balkans, selected texts introduced and translated from the German by Robert Elsie, London 2015, p.19f. 
10.Von Hahn, Johann Georg, The Discovery of Albania. Travel Writing and Anthropology in the Nineteenth-Century Balkans, selected texts introduced and translated from the German by Robert Elsie, London 2015, p.19-24.

11.Dankoff, Robert, Elsie, Robert, Evliya Çelebi in Albania and adjecent Regions (Kosovo, Montenegro, Ohrid), The relevant sections of the Seyahatname edited with translation, commentary and introduction, Leiden 2000, p.87

12.GCDO with Booth, Felicity, Roshi, Elenita, (ed.), Gjirokastra. The essential Guide, Tirana 2009, p.39.

13.ICOMOS approval report, Historic centres of Berat and Gjirokastra (Albania), No. 569bis, Paris 2008

14.GCDO with Booth, Felicity, Roshi, Elenita, (ed.), Gjirokastra. The essential Guide, Tirana 2009, p.38.

15.ICOMOS, UNESCO World Heritage List No. 569 rev, Paris 2005, p.174.

16.Pavlides, Eleftherios, p.1487 in: Paul Oliver (ed.), Vernacular Architecture of the World, London 1997, Part 2.IV.3 Balkans, p.1483-1499. 